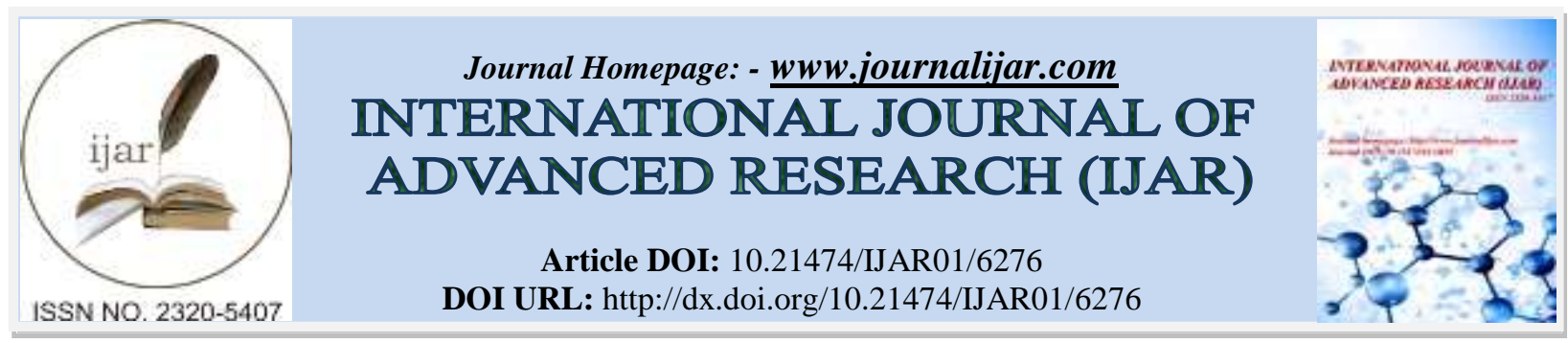

RESEARCH ARTICLE

\title{
PISCICIDAL PLANTS USED BY MALAI PANDARAM TRIBES IN ACHANKOVIL RIVER BASIN, KERALA: AN ETHNOBIOLOGICAL APPROACH.
}

\author{
Arun Sasi $\mathbf{S}^{1}$ and Mahesh Mohan ${ }^{2}$. \\ School of Environmental sciences, Mahatma Gandhi University, Kottayam, Kerala, \\ India-686 560.
}

\section{Manuscript Info}

Manuscript History

Received: 11 November 2017

Final Accepted: 13 December 2017

Published: January 2018

Keywords:-

Ethnobiology Malai Pandarams Piscicidal plants Achankovil River basin.

\section{Abstract}

Malai Pandaram tribes are well known for their nomadic way of life style and inherited wisdom of ethnobiology. An ethnobiological survey for Piscicidal plants used by Malai Pandarams has been conducted during 2013 March to 2015 March in the Achankovil River basin. Information on piscicidal plants and their usage were collected through observation, personal conversation and structured questionnaires among them. 41 plant species belonging to 33 genera and 18 families were found of piscicidal value. The plant species are enumerated in alphabetical order along with families and local names, followed by their ethnobiological uses.

Copy Right, IJAR, 2018,. All rights reserved.

\section{Introduction:-}

Ethnobiology, the scientific study of biological knowledge of particular tribal communities about plants, animals, their interrelationships and uses, shares various methodologies and theoretical frame works has been associated with ethnobotany and ethnozoology ${ }^{1-2}$. Ethnobotany of Kerala is augmented with significant contribution from primogenitors ${ }^{3-9}$. Kerala is remarkable with high biodiversity and cultural diversity possesses 35 tribal communities accounting for about 1.45 per cent of the total population ${ }^{10}$. Most of them are inhabited in the Western Ghats forests and rely on forest resources for their livelihood. Fish has been an integral part of their diet since time immemorial. Traditionally they have been used plants and plant parts for poisoning or stupefying fishes. The uses of poisonous plants for catching fishes make a distinctive attention in the field of ethnobotany in all over the world ${ }^{11-16}$.

Malai Pandarams, a typical regional nomadic forest dwelling community distinguished into three categories, viz., the forest nomads, the colonized and the semi-colonized or semi-nomads ${ }^{17}$. They are settled in the highland and midland region of Achankovil River basin between $9^{0} 09^{\prime} \mathrm{N}-9^{\circ} 17^{\prime} \mathrm{N}$ latitude and $77^{\circ} 11^{\prime}-76^{\circ} 96^{\prime} \mathrm{E}$ longitudes. The altitude varies from $50-1000 \mathrm{~m}$ above msl. The Malai Pandarams contribute $0.49 \%$ of the total tribal population of Kerala and most of them are lived in rural regions.

Ethnoichthyology and ethnobotany are the areas of ethnobiology that examines the indigenous knowledge of fishes and plants for their day-today life of indigenous communities have attracted the attention of both ethnobotanists and ethnozoologists. Documentation of piscicidal plants in the state has an extensive history from imperial period. The usage of fish poisonous plants by the Malayadiyars tribes of Pamba river basin reported by Bourdillon in 1892 was considered as the first report ${ }^{18}$. In 1914 Rama Rao reported that there have been 21 plant species as fish poison in the Travancore region of Kerala ${ }^{19}$. Prasad et al described 28 plants which belong to 23 genera and 16 families were used for fish poisoning in Kasargod district, $\mathrm{Kerala}^{20}$. A review of the available literature revealed that a few 
indigenous communities of the Kerala have been explored to uncover the use of piscicidal plants and documented their ethnobiological utility. The present study examines the ethnobiological knowledge of Malai Pandarams communities in the Achankovil River basin with particular reference to the piscicidal plants used in tribal areas.

\section{Methodology:-}

The study was carried out in the settlements of Malai Pandarams inhabited in the Konni and Achankovil forest division of Achankovil River basin. The river basin is bound on the north by Pamba river and on the south by the basins of Kallada and Pallikkal river. Since time immemorial the basin is coexisted with biodiversity and cultural diversity. The information on ethnobiological knowledge of the Malai Pandaram communities in fish catching was obtained during the period of 2013 March to 2015 March. The piscicidal plants were collected after getting preliminary information from indigenous communities. The plants were collected and identified with the help of regional flora ${ }^{21-22}$. The herbarium sheets were prepared with all the taxonomic details and deposited in the Herbarium at School of Environmental Sciences, Mahatma Gandhi University.

\section{Result And Discussion:-}

Bilateral process of knowledge transfer has been occurs between Malai Pandarams and non tribals inhabited in the Achankovil River basin. Wild edibles and medicinal plants used by the tribes such as Diplazium esculentum (Retz.) Sw. (Churali), Cycas circinalis L. (Kana), Pittosporum neelgherrense Wight \& Arn (Analivegam) etc. are commonly used by non tribes in the region in their day today life. This knowledge transfer leads the non tribes to the usage of piscicidal plant in fish catching. Plant species viz., Gnidia glauca (Fresen.) Gilg., Hydnocarpus pentandra (Ham.) Oken, Tetrameles nudiflora R.Br.and chemicals like $\mathrm{Ca}(\mathrm{ClO})_{2}\left(\right.$ Calcium hypochlorite), $\mathrm{Ca}(\mathrm{OH})_{2}(\mathrm{Calcium}$ hydroxide) and $\mathrm{NH}_{3}$ (Ammonia) are used by the non tribes in the region for poisoning of fishes. A total of 46 species of freshwater fish, belonging to 17 families and 31 genera were reported from the Achankovil Reserve Forests of Achankovil River basin; 14 of this species were endemic to the Western Ghats and three were endemic to Kerala region $^{23-24}$. Malai Pandarams settled in Achankovil River basin contributes $20 \%$ of the total population of them. The sex ratios of females are higher than the male and have equality in social organization and major role in the gathering of fishes, wild edibles and, Non Timber Forest Products (NTFPs). It was observed that the Malai Pandarams forages seasonally in groups of 10-20 peoples with their hunting dogs for gathering of NTFPs They have been practiced three foraging cycle's viz., in the months of November- December, February-May and June-July. Malai Pandarams catches fishes only for sustenance. The survey indicated that the main fish catching methods practiced by them are hand gathering, hook gathering and stupefying.

The hand gathering and stupefying methods are generally used in summer season. When water level declined the indigenous communities chases the fish in the river until it is get exhausted to continue swim and then caught with bare hands. Gonoproktopterus curmuca (Kooral), Puntius sps. (Poovali), Xenentodon cancila (Kokkola), Hyporhamphus limbatus (Kokkola) are the common fish species collected by them using hand picking method. A few fishes collected were used in medicinal purpose also. For example fishes like Anguilla bengalensis (Blanjil), Heteropneustes fossilis (Cherumeen), Mastacembelus armatus (Arakan), Horabagrus brachysoma (Koori), Gonoproktopterus curmuca (Kooral) were used for diseases like Asthma, Anemia, bronchitis, cough, fever etc.

Slow moving river, streams or ponds were selected for fish poisoning. Once the area is selected branches of plants like Madhuca neriifolia (Moon) H.J.Lam.and Acacia caesia (L) Willd. were placed in water, the former for the shade and later to protect fishes from the water bird Microcarbo niger (Neerkakka) and Ardeola grayi (Kokku). Rice, tapioca etc. were put into water as food for fishes. This will attract fishes from various part of the river from the area of poisoning. After one or two days the flow of the river and streams are barred by diverting the water current. Crushed plant parts are put into the water for catching fish.

Present field investigation has recorded a total of 41 species of piscicidal plants belonging to 18 families and 33 genera consisting of 40 species of angiosperms and one species of gymnosperm. The highest numbers of plant species reported were Mimosaceae, Euphorbiaceae and Anacardiaceae. The scientific name, local name, family name, habitat and plant parts used were given in the table 1 . The recorded species occur as various life forms with the majority being tree (11 species) and remaining occurring as shrubs ( 7 species), climbers (5 species) and herb (one species). In addition various plant parts used for fish poison were analyzed; the most frequently used parts were seeds (19spp.) and remaining are barks (16 spp.), fruit (7 spp.), leaves (3spp.), whole plants (3 spp.) and tuber (1 spp.). 


\begin{tabular}{|c|c|c|c|c|c|}
\hline SI No. & Botanical name & Local name & Family & Habit & Parts used \\
\hline 1. & Abrus precatorius $\mathrm{L}$. & Kunni & Fabaceae & $\begin{array}{l}\text { Climbing } \\
\text { shrub }\end{array}$ & Seed \\
\hline 2. & Acacia caesia (L) Willd. & Incha & Mimosaceae & $\begin{array}{l}\text { Climbing } \\
\text { shrub }\end{array}$ & Bark /fruit \\
\hline 3. & Acacia torta (Roxb.) Craib. & Kaarnicha & Mimosaceae & $\begin{array}{l}\text { Climbing } \\
\text { shrub }\end{array}$ & Fruit /bark/stem \\
\hline 4. & Albizia lebbeck (L.) Willd. & Vaka & Mimosaceae & Tree & Bark / fruit \\
\hline 5. & $\begin{array}{l}\text { Anamirta cocculus (L.) } \\
\text { Wight \& Arn. }\end{array}$ & Karandakam & Menispermaceae & $\begin{array}{l}\text { Woody } \\
\text { climber }\end{array}$ & Seed \\
\hline 6. & $\begin{array}{l}\text { Antiaris toxicaria (Pres.) } \\
\text { Leschen. }\end{array}$ & Araanjili & Moraceae & Tree & Bark / seeds \\
\hline 7. & $\begin{array}{l}\text { Archidendron bigeminum } \\
\text { (L.) Nielsen }\end{array}$ & Paranta & Mimosaceae & Tree & Seeds \\
\hline 8. & $\begin{array}{l}\text { Atlantia monophylla (L.) } \\
\text { Corr.Serr. }\end{array}$ & Malanarakam & Rutaceae & Tree & $\begin{array}{l}\text { Dried stem/ bark/ } \\
\text { leaves/ seed }\end{array}$ \\
\hline 9. & Barringtonia acutangula $\mathrm{L}$. & Attupezhu & Barringtoniaceae & Tree & Bark /seed \\
\hline 10. & Calophyllum inophyllum $\mathrm{L}$. & Punna & Clusiaceae & Tree & Leaves/ bark/ seed \\
\hline 11. & Cycas circinalis L. & Kananga & Cycadaceae & Tree & Fruit \\
\hline 12. & $\begin{array}{l}\text { Derris scandens (Roxb.) } \\
\text { Benth. }\end{array}$ & Ponnamvalli & Fabaceae & $\begin{array}{l}\text { Climbing } \\
\text { shrub }\end{array}$ & Seed \\
\hline 13. & Diospyros ebenum Koening. & Karimaram & Ebenaceae & Tree & Leaf / seed \\
\hline 14. & Diospyros paniculata Dalz. & Karivella & Ebenaceae & Tree & Leaf / seed \\
\hline 15. & Entada rheedii Sprengel & Parantakka & Mimosaceae & Liana & Seed \\
\hline 16. & Euphorbia tirucalli $\mathrm{L}$. & Thirukalli & Euphorbiaceae & Shrub & Stem / latex \\
\hline 17. & Gnidia glauca (Fresen.) Gilg. & Nanju & Thymelaeaceae & Shrub & Whole plant \\
\hline 18. & $\begin{array}{l}\text { Harpullia arborea (Blanco) } \\
\text { Radlk. }\end{array}$ & Puzhukolli & Sapandiaceae & Tree & Crushed seeds \\
\hline 19. & Holigarna arnottiana J.Hk. & Cahru & Anacardiaceae & Tree & Bark \\
\hline 20. & $\begin{array}{l}\text { Holigrana grahami }(\mathrm{Wt}) \\
\text { Kurz. }\end{array}$ & Aanacharu & Anacardiaceae & Tree & Bark \\
\hline 21. & $\begin{array}{l}\text { Hydnocarpus kurzii (King) } \\
\text { Warb. }\end{array}$ & Marotti & Flacourtiaceae & Tree & Seed \\
\hline 22. & $\begin{array}{l}\text { Hydnocarpus pentandra } \\
\text { (Ham.) Oken }\end{array}$ & Marotti & Flacourtiaceae & Tree & Seed \\
\hline 23. & Jatropha curcus L. & Kadalavanakku & Euphorbiaceae & Shrub & Seed \\
\hline 24. & $\begin{array}{l}\text { Lagerstroemia microcarpa } \\
\text { Wight }\end{array}$ & Neermaruthu & Lythraceae & Tree & Fruit \\
\hline 25. & Manihot esculenta Crantz. & Cheeni & Euphorbiaceae & Shrub & Tuber \\
\hline 26. & $\begin{array}{l}\text { Prunus ceylanica (Wight.) } \\
\text { Miq. }\end{array}$ & Naykambakam & Rosaceae & Tree & Seed \\
\hline 27. & $\begin{array}{l}\text { Pterospermum diversifolium } \\
\text { Blume }\end{array}$ & Malavuram & Sterculiaceae & Tree & Bark / fruit \\
\hline 28. & $\begin{array}{l}\text { Pterygota alata (Roxb.) R. } \\
\text { Br. }\end{array}$ & Aanathondi & Sterculiaceae & Tree & Fruit \\
\hline 29. & Randia brandisii Gamble & Kara & Rubiaceae & Shrub & Crushed seeds \\
\hline 30. & $\begin{array}{l}\text { Randia dumetorum (Retz.) } \\
\text { Poiret }\end{array}$ & Malankara & Rubiaceae & Tree & Crushed seeds \\
\hline 31. & Sapindus trifoliata $\mathrm{L}$. & Pasakotta & Sapandiaceae & Tree & Seed \\
\hline 32. & $\begin{array}{l}\text { Schleichera oleosa (Lour.) } \\
\text { Oken }\end{array}$ & Poovam & Sapandiaceae & Tree & Seed \\
\hline 33. & Semecarpus anacardium L.f. & Cheru & Anacardiaceae & tree & Seed /bark \\
\hline 34. & Spilanthes calva DC. & Kammalchedi & Asteraceae & Herb & Whole plant \\
\hline 35. & Strychnos nux-vomica L. & Kanjiram & Loganiaceae & Tree & Seed \\
\hline
\end{tabular}




\begin{tabular}{|r|l|l|l|l|l|}
\hline 36. & Terminalia chebula Retz. & Kadukka & Combretaceae & Tree & Bark /seeds \\
\hline 37. & $\begin{array}{l}\text { Terminalia bellirica } \text { (Gaertn) } \\
\text { Roxb. }\end{array}$ & Thanni & Combretaceae & Trre & Bark /seeds \\
\hline 38. & $\begin{array}{l}\text { Tetracera indica } \text { (Christm. } \\
\text { \& Panz.) Merr. }\end{array}$ & Vennel valli & Dilleniaceae & Shrub & Leaves/ fruit \\
\hline 39. & Tetrameles nudiflora R.Br & Cheenimaram & Datiscaceae & Tree & Bark \\
\hline 40. & $\begin{array}{l}\text { Trichilia connaroides } \text { (W.\& } \\
\text { A.) Bentv. }\end{array}$ & Karakkodi & Meliaceae & Tree & Bark / seeds \\
\hline 41. & $\begin{array}{l}\text { Walsura trifolia } \text { (A. Juss.) } \\
\text { Harms. }\end{array}$ & Perillapacha & Meliaceae & Tree & Pulp/ bark \\
\hline
\end{tabular}

\section{Conclusion:-}

The study revealed that the ethnobiological knowledge of Malai Pandarams varies between their settlement types. Tribes living in the interior part of the forest (forest nomads) and living in fringe of the forest (semi colonized) having sound traditional knowledge and great holistic approach to the forest compared to the colonized tribes in Achankovil River basin. The process of assimilation and acculturation among the Malai Pandarams settled in the colonies leads to the deterioration of ethnobiological knowledge. These tribes are inhabited in the river basins of Kallada and Pamba also. Further studies are needed for the complete documentation of piscicidal use of Malai Pandarams in the entire state of Kerala. Plantation forestry, wildfire and over harvesting cause the depletion of piscicidal plants from the forest region. Many of the plant species are extinct from their wild nature. Scientific and sustainable utilization of this species is very important for the conservation of indigenous knowledge and biodiversity.

\section{Acknowledgements:-}

Authors are thankful to the Kerala State Biodiversity Board (KSBB), Government of Kerala for financial assistance in the form of Doctoral Fellowship to first author. The contribution of Malai Pandaram tribes of Achankovil and Konni Forest Division in sharing the information is highly acknowledged.

\section{References:-}

1. Ford RI, Ethnobiology at the millennium: past promise and future prospects, In: Anthropological papers 91, Museum of Anthropology (University of Michigan, Ann Arbor), 2001.1-10.

2. Hunn E. Ethnobotany in four phases. J Ethnobiology, 27(2007)1-10.

3. Manilal KS, Hortus Malabaricus of Van Rheede and Floristic and Ethnobotanical studies in India, $125^{\text {th }}$ Anniv.Sem.Proc, (Madras Herbarium, Coimbatore)1978, 45.

4. Manilal KS, An Ethnobotanical connection between Mushrooms and Dolmens. In: Contribution of Ethnobotany, edited by SK. Jain, (1981), 289-292.

5. Manilal KS, Ethnobotany of the rices of Malabar In: Contribution to Ethnobotany of India. (Botanical Survey of India, Calcutta), (1981), 243-253.

6. Manilal KS, An Ethnobotanic connection between Mushroom and Dolmens, Glimpses of Indian ethnobotany, (Oxford \& IBH Publication, New Delhi), 1981, 321-329.

7. Manilal KS, Linkages of Ethnobotany with other science and disciplines. Ethnobotany. 1(1989), 15-24.

8. Pushpangadan P \& Atal CK, Ethnomedico botanical investigation in Kerala Some primitive tribals of Western Ghats and their herbal medicine. J. Ethnopharmacology, 11(1984) 59-77.

9. Pushpangadan P, Search for new sources of Biodynamic compounds from tribal medicine. Crude Drugs, 7(1) (1986) 40-43.

10. Census report 2011, Government of India.

11. Howes FN, Fish Poison Plants.Bulletin of Miscellaneous Information (Royal Botanic Gardens, Kew), 4 (1930) 129-153.

12. Lamba SS, Indian Piscicidal Plants. Economic Botany 24(2) (1970) 134-136.

13. Neuwinger HD, Plants used for poison fishing in tropical Africa.Toxicon.44 (2004) 417-430.

14. Jonathan GC, Robert A. Burton, Steven G. Woodand Noel L. Owen, Naturally Occurring Fish Poisons from Plants. Journal of chemical education 81(10) (2004)1457-1461. 
15. Jesse Wagstaff D, International Poisonous Plants Checklist. An Evidence Based Reference. (CRC Press, Boca Raton), 2008.

16. Umberto Quattrochi, CRC World Dictionary of Medicinal and Poisonous Plants (CRC Press, Taylor and Francis Group. Boca Raton), 2012.

17. Raju S, A Studies on the little known nomadic primitive tribe: Malai Pandarams. Kerala Forest Department. 2002.

18. Bourdillon TF, Report on the Forests of Travancore. (Government Press, Trivandrum), (1892), 59.

19. Rama Rao M, Flowering Plants of Travancore. (Bishen Singh Mahendra Pal Singh, Dehra Dun. (1914).

20. Prasad K Subrahmanya, Raveendran K, Plants used as fish poison in Kasargod district, Kerala. Journal of Ecobiology 28 (2) (2011): 101-105.

21. Gamble and Fisher, Flora of the Presidency of Madras (Adlard and Son, Limited. London), (1915-1936).

22. Anilkumar N, Sadasivan M, Ravi N, Flora of Pathanamthitta (Western Ghats, Kerala, India). (Daya Publishing House), (2005).

23. Fibin Baby et al., Checklist of the fishes of the Achankovil forests, Kerala, India with notes on the range extension of an endemic cyprinid Puntiuschalakkudiensis. Jott Short Communication, Western Ghats Special Series. 3(7) (2011)1936-194.

24. Sanal Kumar MG, et al., A Comparative study on the diversity of ornamental and food fishes of river Achankovil in relation to various physico-chemical characteristics. International Journal of Scientific Research 2(2) (2013) 410-414. 